\title{
Mating Behavior of a Deep-Sea Squid Revealed by in situ Videography and the Study of Archived Specimens
}

\author{
H. J. T. HOVING ${ }^{1}$ AND M. VECCHIONE ${ }^{2}$ \\ ${ }^{1}$ Monterey Bay Aquarium Research Institute, Moss Landing, California 95039; and \\ ${ }^{2}$ NMFS National Systematics Laboratory, National Museum of Natural History, \\ MRC-153, Smithsonian Institution, P.O. Box 37012, Washington, DC 20013-7012
}

The mating behavior of deep-sea squids is shrouded in mystery. The squids for which mating has been observed use a hectocotylus, a modified arm, for the transfer of sperm packets called spermatophores. However, many deep-sea squid species lack a hectocotylus. We present the first in situ observations of mating behavior in a deep-sea squid that has no hectocotylus but instead uses an elongated terminal organ for the transfer of spermatangia, which are released from the spermatophores and burrow deeply into the female tissue. With remotely operated vehicles (ROVs), we observed two mating pairs of the deep-sea squid Pholidoteuthis adami in the Gulf of Mexico. The male adopted a peculiar position during mating, with its ventral side up and its posterior mantle above the female's head. While the male held the female in what looked like a firm grip, we observed the long terminal organ extending through the funnel of the male, contacting the female dorsal mantle. Examinations of museum specimens show that spermatangia burrow from the outer dorsal mantle into the inner dorsal mantle. This combination of serendipitous in situ observations and archived specimens can be a powerful tool for understanding the behavior of deep-sea animals.

Squids are very successful and abundant molluscs that inhabit the marine environment from coastal waters to the deep sea. Although the use of ROVs in the exploration of the deep sea has led to the discovery of new and often unexpected behaviors of deep-sea squid (1-3), their reproductive biology remains poorly known. For many squid species, mature individuals have never been encountered or

Received 20 June 2012; accepted 5 October 2012.

* To whom correspondence should be addressed. E-mail: hjhoving@ mbari.org are known only from the stomach contents of predators like sperm whales (4). Hence, specifics of the mating behavior in deep-sea squid are mostly inferred from characteristics of dead individuals (5-10). This has led to hypotheses that can only be tested by in situ observations.

During mating, male squid transfer spermatophores to the female. Spermatophores are complex structures that hold millions of spermatozoa (11). The spermatophore holds the spermatangium, an encased sperm mass that is released from the spermatophore during a process known as the spermatophoric reaction $(6,11,12)$. The spermatophoric reaction is triggered by contact with seawater when the spermatophore is outside the male's reproductive system or by physical stimulation of the spermatophore during mating (12). Once the spermatangium is released from the spermatophore, it is able to autonomously attach to or implant into the female's body where it holds the sperm until fertilization of the eggs $(13,14)$. The locations of spermatangia implantation are fixed for some species (e.g., the anterior mantle margin or the base of the ventral arms), but in others spermatangia seem to be randomly distributed over the female's body (15). What enables release of the sperm from the spermatangia is unknown.

Many squid species have a modified arm, the hectocotylus, for the transfer of spermatophores. However, numerous deep-sea species lack a hectocotylus (15). In these squids the terminal part of the spermatophore storage sac is elongated and forms the so-called terminal organ, or penis, which is used for the transfer of spermatophores. Several studies have described specifics of the reproductive system of squid with a long terminal organ; females of these species were observed to have spermatangia deeply implanted in their tissues (5-10). However, mating behavior by this 
group of squids has not previously been observed, and what is known is based on the examination of dead trawl-captured individuals of a few species.

The reason for the paucity in knowledge on deep-sea squid reproduction is the difficulty in studying these animals. Large (and hence more powerfully swimming) individuals are often absent in trawl samples because they are able to avoid nets. ROVs allow the study of animals in situ, but they are noisy and use powerful lights to illuminate the water in front of the vehicle; thus large mature squids may avoid the ROV.

We present the first detailed observation of mating behavior in a deep-sea squid species where spermatophores are transferred with a terminal organ and where spermatangia are deeply implanted into the female. This is the second observation of a mating pair of deep-sea squid observed by submersible. Using ROVs in the Gulf of Mexico, we encountered mating pairs of Pholidoteuthis adami Voss 1956, a large deep-sea squid that has dermal cushions on its mantle (16) and is common in the Gulf of Mexico (17) and in the slope waters of the western North Atlantic (18).

Two pairs of mating squid identified as Pholidoteuthis adami were observed in situ. The first mating pair was observed on 17 July 2006 in the Gulf of Mexico by an ROV operated by Deep Marine Technology, Inc., at a depth of $930 \mathrm{~m}$. Another pair of mating squid was observed by ROV on 13 April 2012 at a depth of $1400 \mathrm{~m}$ and at $28.65^{\circ} \mathrm{N}, 088.46^{\circ} \mathrm{W}$ during an expedition by NOAA Ship Okeanos Explorer in the northern Gulf of Mexico (Fig. 1; Supplemental video [http://www.biolbull.org/ content/supplemental]).

During in situ observations with the ROVs, both pairs were encountered very close to the bottom but not resting on it. The bright lights of the ROV did not seem to disturb the mating pairs at all. The first pair was recorded for $18 \mathrm{~s}$; the second for $1 \mathrm{~min}$ and $50 \mathrm{~s}$ (Fig. 1; video [http://www.biolbull. org/content/supplemental]). While we don't know the size of the individuals in the first mating pair, a comparison with parallel lasers on the ROV (10 cm apart), showed that the second mating pair were each about $680 \mathrm{~mm}$ in mantle length. All squid were dark red/purple in color. Throughout both observations the bodies of the male and female were positioned parallel to each other, the male lying above the female, but headed in the opposite direction, and with his ventral side up (Fig. 1; supplemental video [http://www. biolbull.org/content/supplemental]). The male seemed to have a firm grip on the female. The dorsal arm pair (AI) could not be seen and was presumably located between the bodies of the two individuals. It appears that the second, dorsolateral, arm pair (AII), was positioned along the female's dorsal mantle extending anteriorly along the female. If so, the male's third, ventrolateral arm pair (AIII), then held the female's mantle and were tucked underneath the female's fin pointing toward her posterior mantle. The

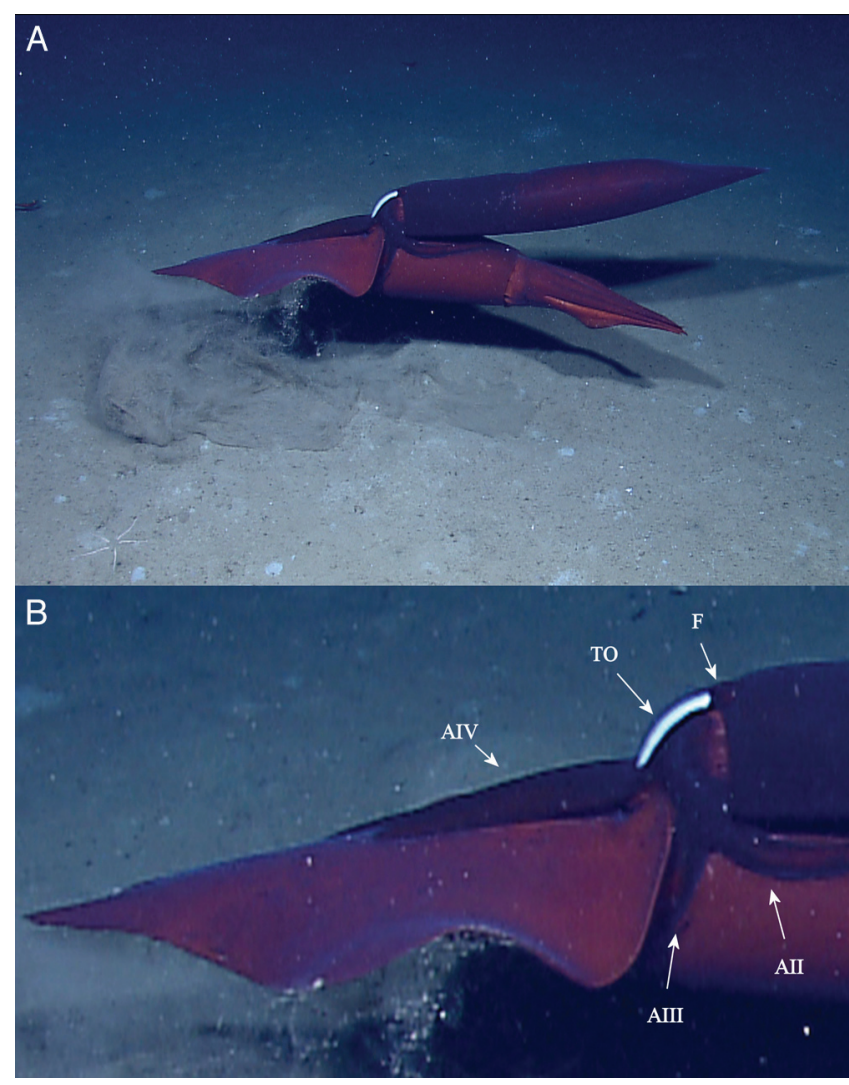

Figure 1. ROV observation of Pholidoteuthis adami. (A) The second observed mating pair, encountered on 13 April 2012. The male is lying above the female, but headed in the opposite direction, with his ventral side up. The terminal organ is the white elongated structure, and can be seen to extend through the funnel. (B) A close-up of the embrace of the male showing the ventral arm pair (AIV), the ventrolateral arm pair III (AIII), the dorsolateral arm pair II (AII), and the terminal organ (TO) extending from the funnel (F). The first, dorsal, arm pair is not visible. Figure courtesy of NOAA Okeanos Explorer Program.

fourth, ventral, arm pair (AIV) seemingly held the female's dorsal mantle, between her fins. No tentacles were observed. The posterior mantle of the male was above the female's head. In both encounters the female was actively swimming primarily using her fins (video [http://www.biolbull.org/ content/supplemental]). The male of the first pair was seen to move its fins actively, but the male of the second pair remained motionless during the entire observation. In both recordings the terminal organ was seen to extend through the male's funnel and seemingly had contact with the female's mantle between the male's ventral arms. Once extended, the terminal organ was not seen to move at any time, and presumably was depositing spermatophores onto the outer mantle of the female. Judging from this mating position, spermatophores are deposited on the dorsal mantle approximately where the fins join the mantle. However, we did not observe spermatophores being expelled by the terminal organ.

Two preserved museum specimens from the US National 


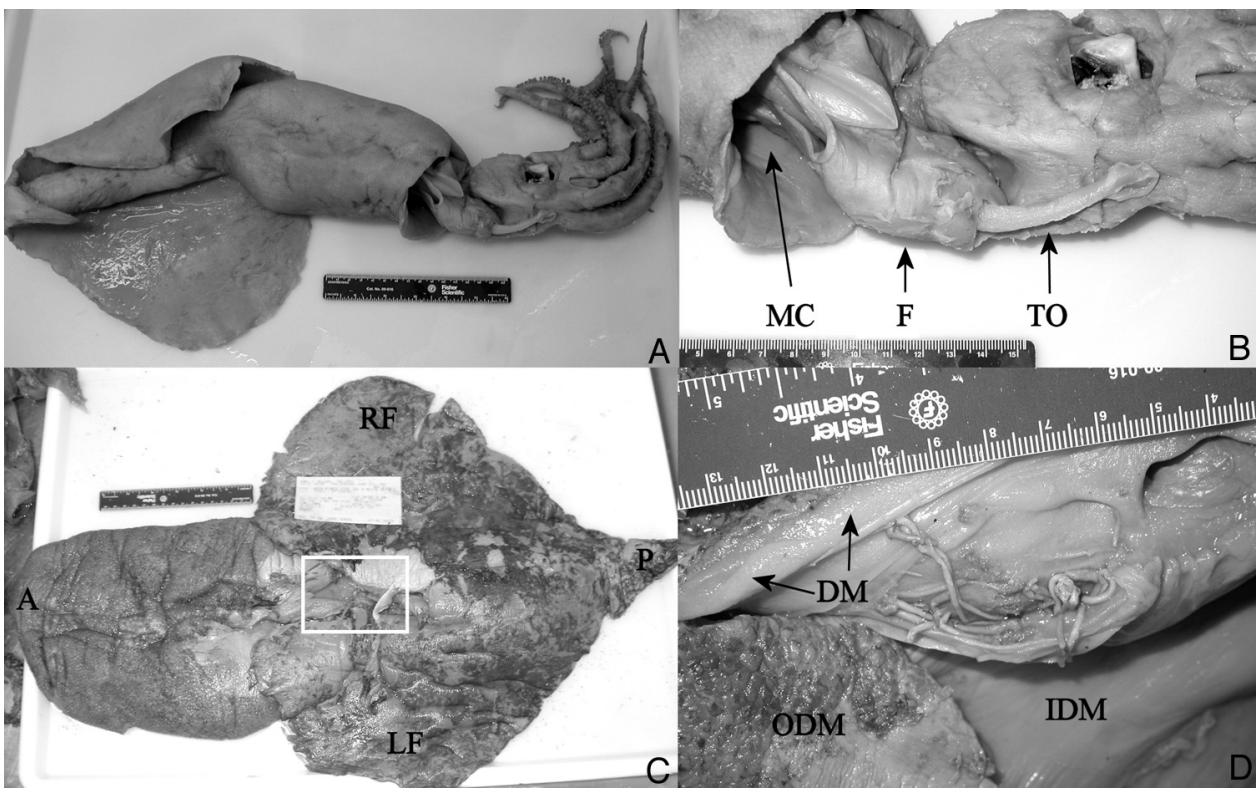

Figure 2. Museum specimens of Pholidoteuthis adami showing (A) a mature male; (B) a close-up of the same male individual as in (A) showing the terminal organ (TO) extending through the funnel (F). The mantle cavity (MC) from which the terminal organ extends is also indicated. (C) Dorsal view of a mantle of a mature female. The head was separated from this mantle. The anterior (A) and posterior (P) sides and the left (LF) and right (RF) fins are indicated. The area where spermatangia have implanted into the dorsal mantle, between the fins, is indicated by a white box. (D) Close-up of the area indicated by the white box in (C) showing several spermatangia deeply implanted into the dorsal mantle tissue. The dorsal mantle has a longitudinal cut. In order to show the spermatangia situated in the dorsal mantle muscle, the dorsal mantle muscle tissue is slightly lifted, showing the section through the mantle muscle (DM), and the associated spermatangia. The inner dorsal mantle (IDM) and the outer dorsal mantle (ODM) are indicated.

Museum of Natural History (USNM) were also examined (Fig. 2). These animals included a mature mated female (USNM 885785) collected by R/V Gyre off Florida in the Gulf of Mexico on 18 April 1984 by trawl at 1170-m depth $\left(28^{\circ} 06^{\prime} 00^{\prime \prime} \mathrm{N}-86^{\circ} 35^{\prime} 18^{\prime \prime} \mathrm{W}\right)$ and a mature male (USNM 885782) collected by R/V Citation off Florida in the Gulf of Mexico on 16 May 1985 at $630-\mathrm{m}$ depth $\left(28^{\circ} 07^{\prime} 38^{\prime \prime} \mathrm{N}-\right.$ $\left.85^{\circ} 51^{\prime} 36^{\prime \prime} \mathrm{W}\right)$.

The mature-male museum specimen (ML $700 \mathrm{~mm}$ ) had its terminal organ extended through its funnel (Fig. 2) similarly to the males observed in situ. The female (ML 660 $\mathrm{mm}$ ) had ripe ova and developing oocytes inside the ovary and ripe ova in both oviducts, suggesting a repeated spawning strategy (19). Small scars were found on its outer dorsal mantle, interpreted as traces of mating. The tissue where spermatangia had penetrated seemed to have been abraded, possibly by the male's beak, but the mantle was too damaged for us to state this conclusively. The locations where spermatangia had penetrated the tissue were visible on the outer dorsal mantle, but the large sperm masses were visible only from inside the mantle (Fig. 2). Between 15 and 20 spermatangia were found embedded in the muscles of the dorsal mantle at about the location of the anterior fin insertions, at the same place where the male was seen to position the terminal organ in the mating events observed in situ.
Encounters with mating pairs of oceanic/deep-sea squid are very rare. Even for Humboldt squid (Dosidicus gigas) whose populations are subject to extensive biological surveys because this large oceanic species supports the largest squid fishery in the world, only two observations of mating pairs exist $(20,21)$. Humboldt squid, like the Japanese common squid Todarodes pacificus, mate in a head-to-head position (22). These species are both in the family Ommastrephidae, which is characterized by elaborate hectocotylization. Pairs of Brachioteuthis beanii (family Brachioteuthidae) were observed by a manned submersible in various positions, some of them presumably being part of mating behavior (23). However, alternative explanations (e.g., cannibalism) could not be excluded.

We report here the first detailed observation of mating behavior in a deep-sea squid that uses the terminal organ for the transfer of deeply implanting spermatangia. The mating pairs of $P$. adami adopt an unexpected position for mating, where the male is upside down, with the posterior mantle above the female's head. Possible reasons for this position include (1) ensuring proper positioning of the spermatangia so sperm can successfully fertilize the eggs during spawning; (2) preventing the female from grabbing, and perhaps eating, him; (3) assuming a position where the female is the least bothered by the transfer of spermatangia, allowing him 
as long as possible in her vicinity; and (4) improving mobility of the terminal organ, which would be restricted between the male and female bodies if the male was not upside down.

In $P$. adami we observed the terminal organ to extend through the funnel to contact the outer dorsal mantle of the female, where spermatophores presumably were deposited. The muscular terminal organ may trigger the release of the spermatangia from the spermatophores, as has been hypothesized for other squid with a long terminal organ (13). Spermatangia in preserved $P$. adami specimens were found deeply implanted into the dorsal mantle tissue of the female, penetrating into the inner mantle epithelium. Deeply implanted spermatangia are found in many other deep-sea squids $(1,5-10,13-15)$ and may have evolved to secure spermatangia in squid species with an active lifestyle but lacking a seminal receptacle for the deposition of spermatangia (14). Although our evidence of the production of wounds by the male in the female is inconclusive, such wounds have been observed in Pholidoteuthis sp. specimens from sperm whale stomachs (K. S. R. Bolstad, Auckland University of Technology; pers. comm.), and from P. massyae from New Zealand (10).

Because spermatangia have been found implanted seemingly nonselectively at various locations on some mated female deep-sea squid, mating is thought to happen quickly $(1,6)$. In P. adami, however, mating is not swift. The $P$. adami male was seemingly holding the female very firmly, and mating was prolonged. The opening of the terminal organ of the museum specimen is narrow and suggests that only one spermatophore is released at a time. This is also observed in male Onykia ingens that were caught by trawl and released spermatophores while being handled onboard. The spermatangia of this deep-sea squid also implant deeply into the female tissue (13). The successful implantation of 15-20 spermatangia probably takes some time. Since spermatangia penetrate into the mantle cavity, fertilization likely happens there. What enables release of the sperm from the spermatangia and how they reach the eggs is unknown.

The use of in situ observations in partnership with examination of archived museum specimens is a powerful combination for investigating the reproductive biology of poorly known deep-sea squid.

\section{Acknowledgments}

We are grateful to Ian MacDonald for providing the 2006 observations and to Richard E. Young and Bruce Robison for their feedback on an earlier version of this manuscript. HJH received research funding from the David and Lucile Packard Foundation, the Netherlands Organization for Scientific Research (NWO), and the Schure-Beijerinck-Popping-Funds.

\section{Literature Cited}

1. Hoving, H. J. T., S. L. Bush, and B. H. Robison. 2012. A shot in the dark: same-sex sexual behaviour in a deep-sea squid. Biol. Lett. 8: 287-290.

2. Robison, B. H., K. R. Reisenbichler, J. C. Hunt, and S. H. D. Haddock. 2003. Light production by the arm tips of the deep-sea cephalopod Vampyroteuthis infernalis. Biol. Bull. 205: 102-109.

3. Vecchione, M., R. E. Young, A. Guerra, D. J. Lindsay, D. A. Clague, J. M. Bernhard, W. W. Sager, A. F. Gonzalez, F. J. Rocha, and M. Segonzac. 2001. Worldwide observations of remarkable deep-sea squids. Science 294: 2505.

4. Clarke, M. R. 1980. Cephalopoda in the diet of sperm whales of the southern hemisphere and their bearing on sperm whale biology. Discov. Rep. 37: 1-324.

5. Hoving, H. J. T., M. A. C. Roeleveld, M. R. Lipinski, and Y. Melo. 2004. Reproductive system of the giant squid Architeuthis in South African waters. J. Zool. Lond. 264: 153-169.

6. Hoving, H. J. T., M. R. Lipinski, and J. J. Videler. 2008. Reproductive system and the spermatophoric reaction of the mesopelagic squid Octopoteuthis sicula (Rüppell, 1844) (Cephalopoda: Octopoteuthidae) from southern African waters. Afr. J. Mar. Sci. 30: 603-612.

7. Hoving, H. J. T., M. R. Lipinski, J. J. Videler, and K. S. R. Bolstad. 2010. Sperm storage and mating in the deep-sea squid Taningia danae Joubin, 1931 (Oegopsida: Octopoteuthidae). Mar. Biol. 157: 393-400.

8. Jackson, G. D., and C. H. Jackson. 2004. Mating and spermatophore placement in the onychoteuthid squid Moroteuthis ingens. $J$. Mar. Biol. Assoc. UK 84: 783-784.

9. Norman, M. D., and C. C. Lu. 1997. Sex in giant squid. Nature 389: $683-684$.

10. O'Shea, S., G. D. Jackson, and K. S. Bolstad. 2007. The nomenclatural status, ontogeny and morphology of Pholidoteuthis massyae (Pfeffer, 1912) new comb (Cephalopoda: Pholidoteuthidae). Rev. Fish Biol. Fish. 17: 425-435.

11. Mann, T. 1984. Spermatophores: Development, Structure, Biochemical Attributes and Role in the Transfer of Spermatozoa, SpringerVerlag,. Berlin. 217 pp.

12. Marian, J. E. A. R. 2011. Spermatophoric reaction reappraised: novel insights into the functioning of the loliginid spermatophore based on Doryteuthis plei (Mollusca: Cephalopoda). J. Morphol. 273: $248-278$.

13. Hoving, H. J. T., and V. Laptikhovsky. 2007. Getting under the skin: autonomous implantation of squid spermatophores. Biol. Bull. 212: $177-179$.

14. Marian, J. E. A. R. 2011. A theoretical model to explain spermatophore implantation in cephalopods (Mollusca: Cephalopoda), and a discussion on its evolutionary origins and significance. Biol. J. Linn. Soc. 105: 711-726.

15. Nesis, K. N. 1995. Mating, spawning and death in oceanic cephalopods: a review. Ruthenica 6: 23-64.

16. Roper, C. F. E., and C. C. Lu. 1990. Comparative morphology and function of dermal structures in oceanic squids (Cephalopoda). Smithson. Contrib. Zool. 493: 1-40.

17. Voss, G. L. 1956. A review of the cephalopods of the Gulf of Mexico. Bull. Mar. Sci. Gulf Caribb. 6: 85-178.

18. Vecchione M. 2001. Cephalopods of the continental slope east of the United States. Pp. 153-60 in Island in the Stream: Oceanography and Fisheries of the Charleston Bump, G. Sedberry, ed. American Fisheries Society, Bethesda, MD.

19. Laptikhovsky, V. V., A. I. Arkhipkin, and H. J. T. Hoving. 2007. Reproductive biology in two species of deep-sea squids. Mar. Biol. 152: $981-990$

20. Gilly, W. F., A. E. Carl, A. S. Cesar, C. Susana, B. Gastón, and B. Michael. 2006. Spawning by jumbo squid Dosidicus gigas in San 
Pedro Mártir Basin, Gulf of California, Mexico. Mar. Ecol. Prog. Ser. 313: $125-133$.

21. Nigmatullin, C., K. N. Nesis, and A. I. Arkhipkin. 2001. A review of the biology of the jumbo squid Dosidicus gigas (Cephalopoda: Ommastrephidae). Fish. Res. 54: 9-19.
22. Okutani, T. 1983. Todarodes pacificus. Pp. 201-214 in Cephalopod Life Cycles, P. R. Boyle, ed. Academic Press, London.

23. Roper, C. F. E., and M. Vecchione. 1996. In situ observations on Brachioteuthis beanii (Verrill): paired behavior, probably mating (Cephalopoda, Oegopsida). Am. Malacol. Bull. 13: 55-60. 